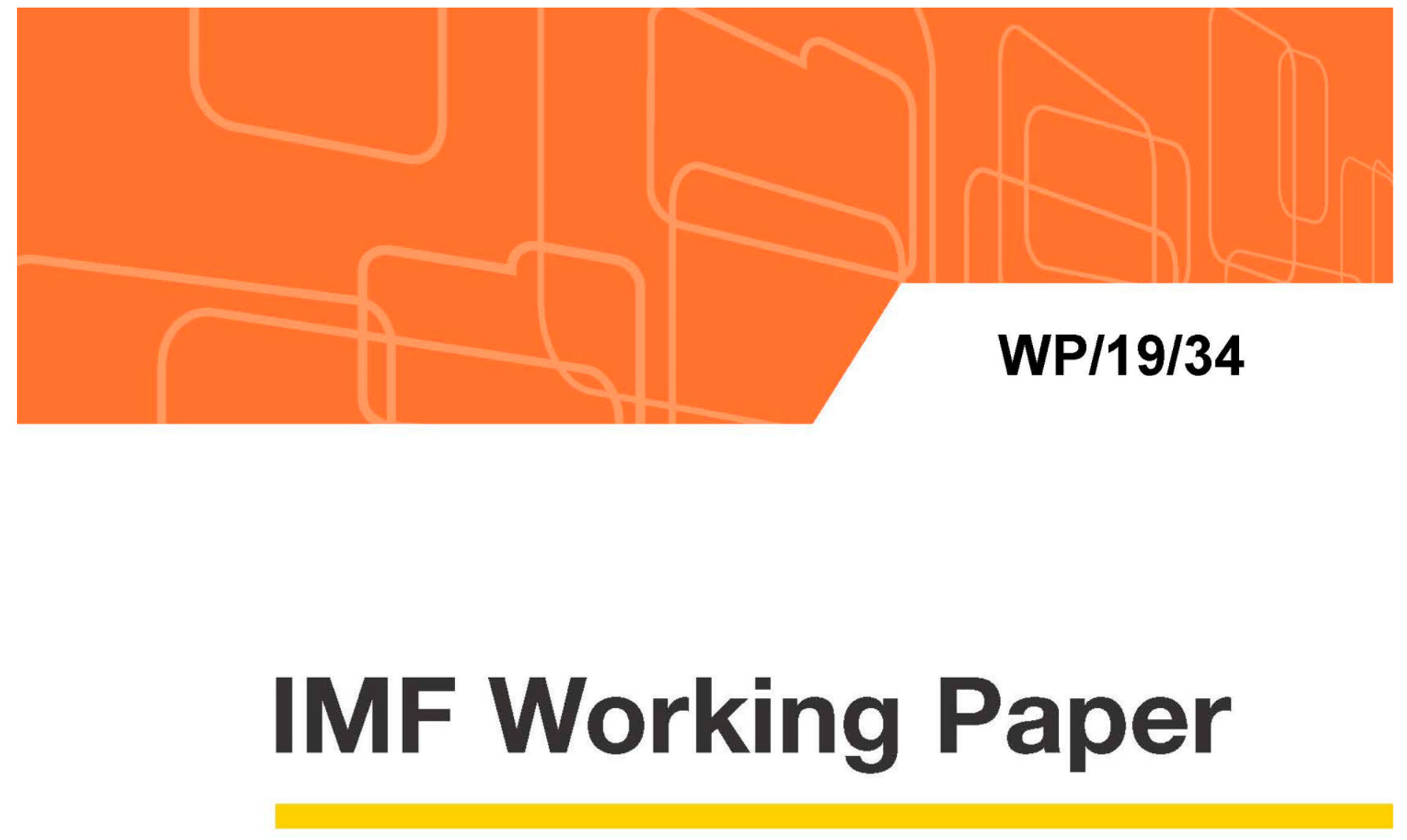

\title{
Inequality of Opportunity, Inequality of Income and Economic Growth
}

by Shekhar Aiyar and Christian Ebeke

IMF Working Papers describe research in progress by the author(s) and are published to elicit comments and to encourage debate. The views expressed in IMF Working Papers are those of the author(s) and do not necessarily represent the views of the IMF, its Executive Board, or IMF management.

$$
\text { I N T E R N A T I O N A L M O N E T A R Y F U N D }
$$




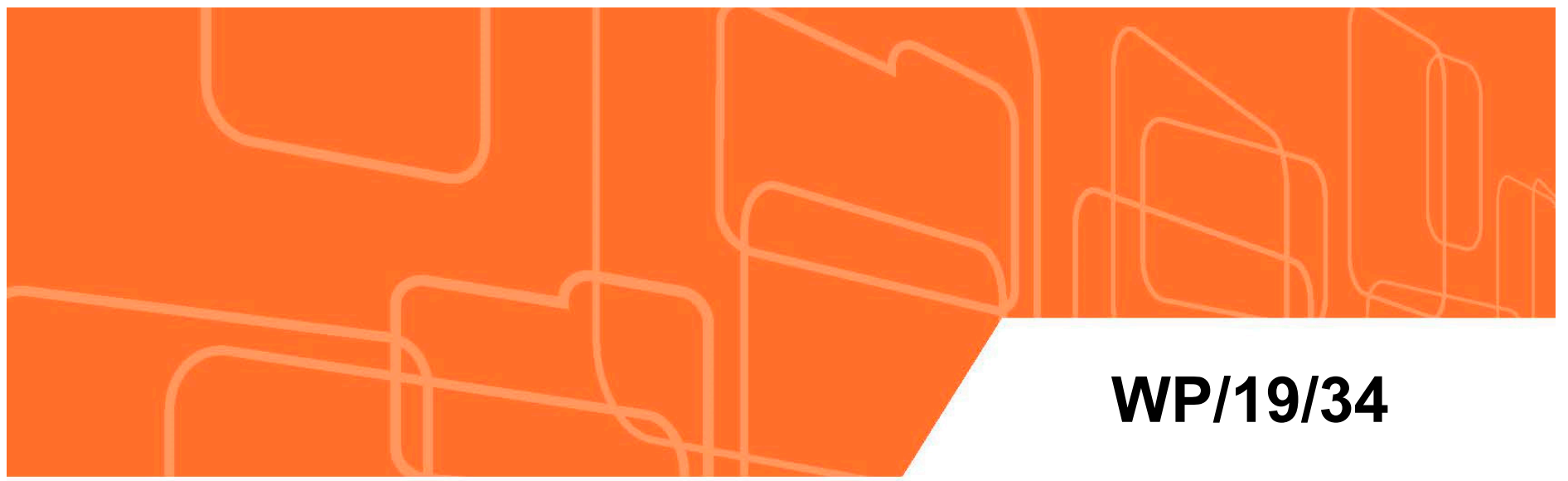

IMF Working Paper

Inequality of Opportunity, Inequality of Income and Economic Growth

by Shekhar Aiyar and Christian Ebeke

IMF Working Papers describe research in progress by the author(s) and are published to elicit comments and to encourage debate. The views expressed in IMF Working Papers are those of the author(s) and do not necessarily represent the views of the IMF, its Executive Board, or IMF management.

I N T E R N A T I O N A L M O N E T A R Y F U N D 


\title{
IMF Working Paper
}

European Department

\section{Inequality of Opportunity, Inequality of Income and Economic Growth \\ Prepared by Shekhar Aiyar and Christian Ebeke}

February 2019

\section{IMF Working Papers describe research in progress by the author(s) and are published to elicit comments and to encourage debate. The views expressed in IMF Working Papers are those of the author(s) and do not necessarily represent the views of the IMF, its Executive Board, or IMF management.}

\begin{abstract}
We posit that the relationship between income inequality and economic growth is mediated by the level of equality of opportunity, which we identify with intergenerational mobility. In economies characterized by intergenerational rigidities, an increase in income inequality has persistent effects - for example by hindering human capital accumulationthereby retarding future growth disproportionately. We use several recently developed internationally comparable measures of intergenerational mobility to confirm that the negative impact of income inequality on growth is higher the lower is intergenerational mobility. Our results suggest that omitting intergenerational mobility leads to misspecification, shedding light on why the empirical literature on income inequality and growth has been so inconclusive.
\end{abstract}

JEL Classification Numbers: D3, D63, O43, O47

Keywords: Intergenerational Mobility, Income Inequality, Growth

Author's E-Mail Address: saiyar@,imf.org; cebeke@,imf.org 


\section{CONTENTS}

ABSTRACT

I. INTRODUCTION

II. MEASURES OF INTERGENERATIONAL MOBILITY ACROSS COUNTRIES 포

III. BASELINE SPECIFICATION AND RESULTS

A. Baseline Specification

B. Results

IV. ROBUSTNESS CHECKS

A. Controlling for Nonlinearity

B. Initial Gini or Intergenerational Mobility?

C. Endogeneity of Income Inequality

V. POLICIES TO LEVEL THE PLAYING FIELD

VI. CONCLUSION

VII. APPENDIX

VIII. REFERENCES 


\section{INTRODUCTION}

The subject of income inequality has exercised economists for as long as there have been economists. ${ }^{1}$ But the topic has gained new prominence since the Great Recession. Several eminent authors have argued that income inequality is a major, or the major, social issue of our time (Stiglitz, 2013; Picketty, 2014; and Milanovic, 2015). This is underpinned by the empirical observation that market income inequality - as measured by the Gini coefficienthas risen substantially since about the mid-1970s in industrial economies; a development contrasting unfavorably with a long prior period, when inequality declined from the high levels prevailing at the beginning of the twentieth century (Peterson, 2017).

The rise in market income inequality is often cited as an important contributor to rising populism, societal stress and demands for protection (Alesina and Rodrik, 1994; Persson and Tabellini, 1994; and Alesina et al., 2017). There is a large literature in the social sciences on the tendency for economic insecurity to beget authoritarian and nativist political parties (see Ingleheart and Norris, 2016, for a survey). The modern version of this politico-economic argument typically focuses on the growing gaps between winners and losers from global trade or on rising skill-premia due to the march of technology, both of which could drive demand for protectionism. Moreover, stagnant middle-class wages and limited job mobility have been advanced as powerful motives for resentment of "outsiders" seen as competing for jobs and benefits (Inglehart, 2016), especially in an era where growing social fragmentation and secularization have eroded traditional collective structures (Inglehart and Norris, 2011). For these and many other reasons, high and persistent income inequality is intrinsically undesirable.

However, assessing whether higher income inequality retards economic growth has proved challenging, and is much disputed in the literature. Theoretically, the effect can go either way. An increase in income inequality arising, say, from substantial rewards to risky entrepreneurship and innovation, could boost economic growth. By contrast, higher inequality could impair growth if low-income households are persistently less productive because of slower human capital accumulation and greater financial exclusion. Empirically, too, there is little consensus. Some studies have found a significant and negative effect of inequality on growth and its duration (Ostry and Berg, 2011; Ostry et al., 2014; and Cingano, 2014). But others have found no systematic negative effect of inequality on growth (Forbes, 2000; Panizza, 2002; and Kraay, 2015). And some authors have sought to show that the relationship is non-linear (Banerjee and Duflo, 2003; and Brueckner and Lederman, 2015).

A recent strand of the literature has used single-country studies to emphasize the role of inequality of opportunity. Inequality is partitioned into a component approximating

\footnotetext{
${ }^{1}$ See Rasmussen (2016) for an introduction to Adam Smith's published views and correspondence on inequality.
} 
inequality of opportunity and a residual component measuring inequality due to effort. ${ }^{2} \mathrm{~A}$ number of studies exploit the variability of U.S. states data to demonstrate that inequality of opportunity affects negatively the future income growth of the poor and positively that of the rich (Marrero and Rodriguez, 2013; Hsieh et al., 2013; Bradbury and Triest, 2016; and Marrero et al., 2016). The rationale is that inequality of opportunity may harm economic growth because it hinders human capital accumulation by low-income individuals. ${ }^{3}$ Moreover, perceptions of unequal opportunities, which affect individual aspirations, may also reduce investments in human capital.

Inequality of opportunity has received less attention in the cross-country literature, mainly due to the difficulty in measuring equality of opportunity in a comparable manner across countries. But there have been important recent advances in this area, as described in the next section, with equality of opportunity measured using cross-country data on various indices of intergenerational mobility, such as the elasticity of an individual's income (or education) to parent's income (or education).

Our central hypothesis is that in economies characterized by low equality of opportunity, income inequality exerts a greater drag on growth. An increase in income inequality tends to become entrenched across generations due to various market failures connected with social stratification. This retards growth, for example by holding back human capital development or causing talent misallocation. On the other hand, in countries with high equality of opportunity, an increase in income inequality is easily reversed precisely because lowincome people have access to the same opportunities as others. In such societies, therefore, an increase in income inequality is less harmful to growth.

Various mechanisms can be envisaged through which inequality of opportunity might mediate the marginal effect of income inequality on growth. Consider three examples. First, if there is unequal access to education, then an income shock could lead to lost educational opportunities, resulting in less aggregate human capital accumulation and therefore slower future productivity growth. ${ }^{4}$ Second, structural rigidities in labor markets could create unequal opportunities for insiders and outsiders. In an economy characterized by high structural rigidities a shock that worsens the income distribution could further disadvantage outsiders. Hysteresis effects could then translate this disadvantage into a longer lasting drag on growth. A third mechanism could relate to unequal access to finance. In the presence of

\footnotetext{
${ }^{2}$ Using an ex-ante criterion, population is partitioned according to individuals' circumstances and inequality of opportunity is evaluated in terms of differences between individuals endowed with the same circumstances, so that inequality of opportunity is represented by the between-group component of the overall inequality.

${ }^{3}$ The theory behind this idea has been explored at length in the literature, dating back to the classic paper by Galor and Zeira (1993), where income inequality in the presence of financial constraints prevents poor families from investing optimally in schooling, thereby harming growth.

${ }^{4}$ There is a lengthy cross-country literature documenting the relationship between aggregate human capital accumulation and economic growth (e.g. Barro, 1991; Benhabib and Speigel, 1994). Aiyar and Feyrer (2002) further decompose the relationship to show that the impact of greater educational attainment is exercised mainly through higher total factor productivity.
} 
credit constraints, an income shock could translate into squandered investment opportunities among the lower percentiles of the income distribution, resulting in lower aggregate growth.

In our empirical work we will remain agnostic about the precise channels through which inequality of opportunity mediates the growth-income inequality relationship, focusing instead on evidence for the more basic proposition that it does influence the relationship. The next section of the paper describes recent developments in measuring intergenerational mobility on a cross-country comparable basis, and discusses the variables that we will use from this literature. Section 3 describes our baseline dynamic panel specification and reports our main results. Section 4 details a range of robustness tests, including testing our specification against non-linear variants suggested by the literature, and augmenting the basic specification with external instruments for income inequality. Section 5 dwells briefly on some policy implications of our results. Section 6 concludes.

\section{Measures of Intergenerational Mobility ACross Countries}

Estimating intergenerational mobility is much more difficult than measuring cross-sectional income inequality. This is mainly because of the extensive data requirements and the challenges of translating theoretical concepts into practical measures. But there is a growing literature in which inequality of opportunity is captured by the degree of intergenerational (im)mobility. This is often approximated using cross-country data on the elasticity of son's income (or education) to father's income (or education), i.e., the percentage difference in earnings (or education level) in the child's generation from that of the parent's generation. ${ }^{5}$ As noted by Corak (2013), the literature has mainly focused on father-son relationships to avoid the more complicated analyses needed to address the changing role of women in the labor force. It is not that studies of mothers, daughters, and the marriage market do not exist, but rather that father-son analyses are more common in the literature and thus available for a broader set of countries.

Corak (2016) provides an account of some of the difficulties involved in making these calculations: to accurately measure the intergenerational earnings elasticity requires estimates of the lifetime earnings prospects of both parents and their children. Because earnings tend to rise over the life cycle, but annual earnings fluctuate a great deal, good estimates of lifetime earnings require obtaining several years of earnings data during a period in the life cycle when individuals are well established in their career jobs (typically, when they are 40 to 50 or so years of age), and these estimates must be available for both the parent and the child. As such the members of a family have to be followed and connected to each other over a period that spans several decades. The data-intensive process behind the estimation of these elasticities makes it very difficult to generate time series of comparable intergenerational elasticities.

Notwithstanding these challenges, the literature has evolved with the availability of more accurate and more representative data. Intergenerational income elasticities for around 22

\footnotetext{
${ }^{5}$ For example, an intergenerational elasticity in earnings of 0.6 tells us that if one father makes 100 percent more than another then the son of the high-income father will, as an adult, earn 60 percent more than the son of the relatively lower-income father.
} 
countries are reported in Corak (2016). The study provides estimates of the intergenerational elasticity between father and son earnings for the United States and 21 other countries from published studies, which are then adjusted to ensure cross-country comparability using the methods described in Corak (2006). These elasticities between paternal earnings and a son's adult earnings are based on cohorts of children born during the early to mid-1960s and their adult outcomes are measured in the mid to late-1990s. A study by Hertz et al. (2007) provides reliable cross-country estimates of intergenerational persistence in schooling (inheritance of educational status) for 42 countries. The authors estimate the intergenerational education elasticities using comparable survey data from countries. The survey years - which include information on parental education - fall between 1985 and 2004. Survey respondents are restricted to those in the age bracket 20 to 69; thus, all respondents were born between 1916 and 1984.

More recently the World Bank has released its Global Database on Intergenerational Mobility (GDIM, 2018), a major advance documented in Narayan et al. (2018). The database contains cross-country comparable estimates of intergenerational income and education elasticities for cohorts born in the 1940s, 1950s, 1960s, 1970s, and 1980s for 111 countries. However, coverage differs by country and variable. Only a single data point by country is available for the elasticity of son's income to father's income (for the cohort born in the 1960s). For the education elasticity, the coverage is more extensive, with between 3 and 5 data points available by country over the period 1940-80).

The GDIM provides a useful cross-check to the intergenerational elasticities reported by Corak for earnings and by Hertz for education. Such a cross-check is especially valuable in light of the inherent complexity of making cross-country comparable intergenerational estimates. The scatter plots in Figure 1 show that there is substantial — although not perfectagreement on the cross-country dispersion of intergenerational mobility between the GDIM database and the Corak / Hertz data. We will use all three sources in our empirical work.

Figure 1. Correlations Between International Estimates of Intergenerational Mobility
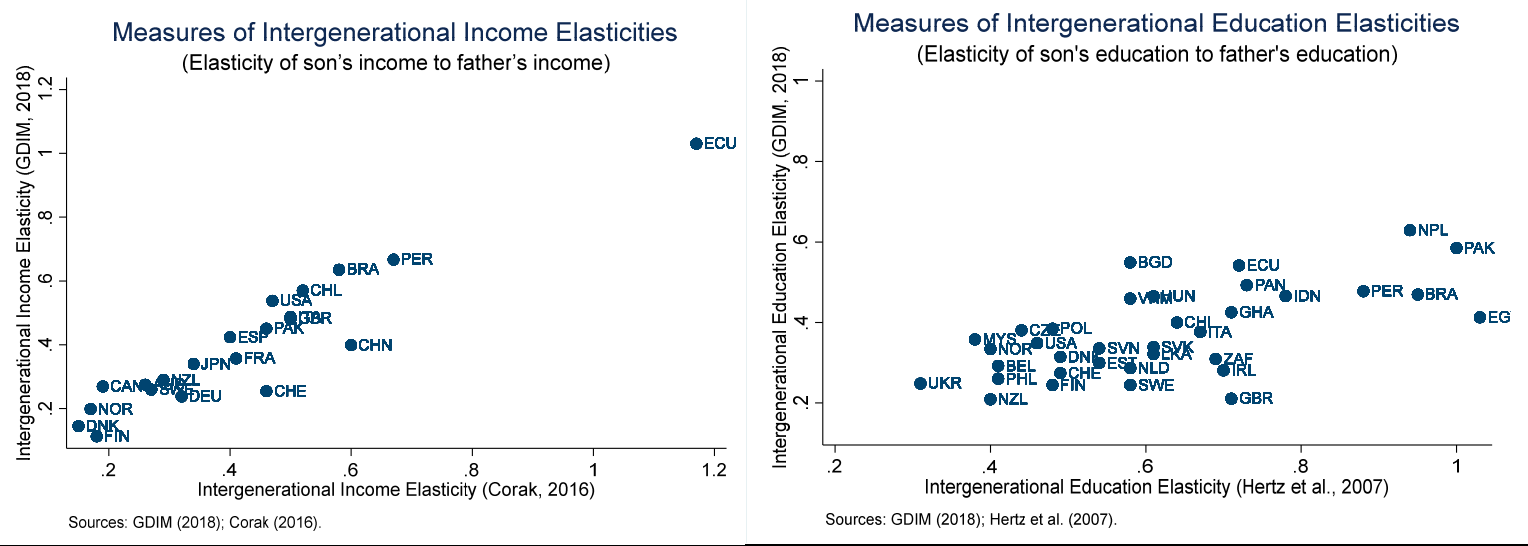


\section{BASELINE SPECIFICATION AND RESULTS}

\section{A. Baseline Specification}

The chief innovation of our study is to model per capita income growth as a function of both income inequality and its interaction with a measure of inequality of opportunity. Our baseline specification takes the following form:

$$
\text { GROWTH }_{i \tau}=\rho y_{i \tau-1}+\left(\theta_{1}+\theta_{2} \mathrm{IM}_{\mathrm{i} .}\right) \cdot \mathrm{GINI}_{\mathrm{i \tau}-1}+\Gamma \mathrm{X}_{\mathrm{i} \tau-1}+\mathrm{u}_{\mathrm{i}}+\gamma_{\tau}+\epsilon_{\mathrm{i \tau}},(1)
$$

where GROWTH denotes the 5-year nonoverlapping average of real per capita GDP growth in each country $i$ observed over each sub-period $\tau$ with raw data starting from 1960; y denotes $(\log )$ real GDP per capita; and $u_{i}$ and $\gamma_{\tau}$ denote country-fixed effects and periodspecific dummies that account for time-invariant unobservable factors at the country level and common shocks to countries, respectively.

$\mathrm{IM}_{\mathrm{i}}$ is our indicator of intergenerational immobility (with higher values corresponding to less mobility). We use four separate cross-country comparable estimates: two estimates of the intergenerational elasticity of earnings (drawn from Corak, 2016; and GDIM, 2018) and two estimates of the intergenerational elasticity of education (from Hertz et al., 2007; and GDIM, 2018). These indicators are time invariant within countries and are treated in the model as predetermined. As discussed earlier, the Corak and Hertz studies provide only a single data point for each country, as does the GDIM data for intergenerational (father-son) earnings. Only the GDIM data for intergenerational education has more than one observation per country encompassing the 1940-80 period; here we use the average of all observations by country. The variable $I M_{i}$ only enters the model in interaction with the Gini, as its additive term is fully absorbed by the country fixed effects.

Income inequality is measured using the Gini coefficient, taken from a comprehensive dataset (All the Ginis) compiled by Branko Milanovic. ${ }^{6}$ This global panel dataset of highquality Gini measurements includes only those Ginis that have been calculated from household surveys. It excludes all Gini estimates produced by regressions or short-cut methods, making it probably the most reliable cross-country dataset yet assembled on income inequality. The database covers 166 countries over the years 1950 to 2015, and includes 4437 separate Ginis. It is compiled from nine separate sources (LIS, SEDLAC, SILC, ECA, WYD, POVCAL, WIDER, CEPAL, and also individual studies) which are used to create a single standardized Gini variable. ${ }^{7}$ Like the dependent variable, the income inequality variable is

\footnotetext{
${ }^{6}$ For a good discussion of this dataset and a comparison with other data sources, see Smeeding and Latner (2015).

${ }^{7}$ Another dataset widely used in the cross-country literature on income inequality is Solt (2016), the so-called Standardized World Income Inequality Database (SWIID). This dataset achieves a wider coverage of countries over time using data from various sources, with cross-country comparability evaluated in terms of success in predicting the Luxembourg Income Study (LIS) dataset. The main issue with the SWIID dataset relative to the Milanovic database is that the bulk of observations is predicted; its main advantage is a larger number of observations and countries. Our reported results are robust to using this database instead of the Milanovic data, with details available upon request.
} 
averaged over each five-year period. It enters the model with a one period lag to reduce the possibility of reverse causality.

$\mathrm{X}$ is a matrix of covariates that are standard in cross-country growth regressions using panel data (see for example Aghion et al., 2009 or Aiyar et al., 2018). It includes investment in percent of GDP, trade openness (measured by exports plus imports divided by GDP), and the average years of secondary schooling (in logs) as a proxy for human capital. These data are from the World Bank. We also control for the initial lagged per capita income level to capture beta convergence. Data on real per capita GDP in PPP terms comes from the Penn World Tables. The sample comprises all countries for which we have data on intergenerational earnings or intergenerational education elasticities. Sample statistics for the full set of variables are presented in Table A in the Appendix.

Our prior is that widening income disparities will retard per capita growth disproportionately in countries exhibiting a high degree of intergenerational immobility. That is, we expect that $\theta 2<0$. If, in addition, $\theta 1 \geq 0$, so that the direct impact of income inequality on growth is positive, then a threshold arises for intergenerational immobility:

$$
\partial \mathrm{GROWTH}_{\mathrm{i \tau}} / \partial \mathrm{GINI}_{\mathrm{i} \tau-1}=\theta_{1}+\theta_{2} \mathrm{IM}_{\mathrm{i}}=0 \rightarrow \mathrm{IM}^{*}=-\theta_{1} / \theta_{2}
$$

where $I M^{*}$ denotes the threshold of intergenerational earnings or education elasticities beyond which income inequality (GINI) unambiguously retards growth.

Estimating (1) requires a number of adjustments. Within-country changes in income inequality $(g)$ are not necessarily independent of growth shocks. Higher growth could lower income inequality if it benefits the poor more than the rich; and it could raise income inequality if it does the opposite. By lagging the Gini variable in the model, we have reduced somewhat the likelihood of such reverse causality. However, endogeneity issues driven by measurement error and/or omitted variables could still bias the results. Moreover, the OLS estimator is inconsistent because the lagged per capita income variable is correlated with the error term in the presence of fixed effects (Nickell bias). We therefore implement an instrumental variables strategy. The equation in levels and the equation in first differences are combined in a system and estimated with an extended System-GMM estimator that allows for the use of lagged differences and lagged levels of the explanatory variables as instruments (Blundell and Bond, 1998). The number of lags of the endogenous variable has been limited to avoid overfitting bias due to instrument proliferation (Roodman, 2009). Two specification tests are used to check the validity of the instruments. The first is the standard Hansen test for overidentifying restrictions. The second test examines the hypothesis that there is no second-order serial correlation in the first-differenced residuals.

\section{B. Results}

Our main result is that income inequality reduces growth more the lower is intergenerational mobility (Table 1). Column 1 shows that if growth is regressed on income inequality alone, the results are inconclusive, mirroring the inconclusive nature of the empirical literature. It is the interaction between intergeneration mobility and income inequality that is crucial to the impact on growth (columns 2-5). Regardless of the type of intergenerational elasticity 
(earnings or education), and regardless of the data source (GDIM, 2018; Corak, 2016; and Hertz et al., 2007), the interaction term between the Gini and the intergenerational elasticity is significantly negative.

Moreover, the effect is economically very meaningful. To give a flavor of the magnitudes: an increase in income inequality by one standard deviation in the pooled sample (corresponding to 10 units of Gini expressed in percentage points) will knock 0.5 percentage points off average growth in the next five-year period for a level of intergenerational income elasticity set at the $25^{\text {th }}$ percentile (roughly where Japan is situated in the distribution) as opposed to 1.3 percentage points reduction at the $75^{\text {th }}$ percentile (roughly where Brazil is situated in the distribution). ${ }^{8}$

The threshold level of inequality of opportunity corresponds to intergenerational elasticities of about 0.3 , when focusing on the GDIM specifications which have a larger sample size. This means that 70 to 75 percent of the countries in our sample fall above this threshold, implying that income inequality has an unambiguously negative effect on growth. This includes major industrial countries such as the U.S., Japan, U.K., and most countries in the euro area, as well as major emerging economies such as China, India, and Brazil. However, note that our estimate of the linear impact of Gini on growth is not very precise, and cannot be distinguished from zero in three out of four specifications. Of course, if $\theta_{1}=0$ then there is no threshold effect, and higher income inequality always retards growth (albeit disproportionately so in countries with low intergenerational mobility).

\section{ROBUSTNESS CHECKS}

\section{A. Controlling for Nonlinearity}

Some authors have suggested that the inconclusive nature of the empirical literature owes to the problems inherent in fitting a linear specification to a nonlinear relationship between income inequality and economic growth. Most prominently, Banerjee and Duflo (2003), argue for the importance of a quadratic relationship between the Gini co-efficient and growth.

Do our baseline results simply capture nonlinearities in the growth-inequality relationship? We test this by including the square of the Gini coefficient in our basic specification. Allowing income inequality to enter the estimating equation in quadratic form makes no qualitative difference to the baseline result that the negative effect of inequality on growth is stronger the lower is intergenerational mobility (Table 2). The results remain significant regardless of the measure of intergenerational immobility (earnings or education). Moreover, the square term of income inequality is not significant. This could suggest that the

\footnotetext{
${ }^{8}$ Note that this experiment is based on a one standard deviation increase in the Gini coefficient for the pooled sample of all Ginis, where most of the variation is accounted for by between-country rather than within-country dispersion. This is arguably an implausibly "large" shock to the Gini. Alternatively, therefore, consider a different experiment in which income inequality rises by one standard deviation of the within-country distribution. This would retard growth by about 0.25 percentage points in countries at the $25^{\text {th }}$ percentile of intergenerational income elasticity, and by about 0.65 percentage points in countries at the $75^{\text {th }}$ percentile.
} 
nonlinearities reported by previous studies could be capturing underlying differences in inequality of opportunity.

\section{B. Initial Gini or Intergenerational Mobility?}

Another concern is that our specification is simply picking up the effect that the initial level of income inequality might have on the impact of future changes in the Gini co-efficient on growth. Perhaps a society which starts with a very unequal income distribution will suffer greater growth losses when inequality rises further, compared with a society where inequality rises from a modest initial level.

This is a key concern given that there is in fact a well-documented empirical association between income inequality at a given point in time, and the country's level of intergenerational mobility. The literature has named this relationship the "Great Gatsby Curve" (Andrews and Leigh, 2009; and Corak, 2013). And unsurprisingly, this relationship is evident in our data. Figure 2 plots the GDIM intergenerational earnings elasticity used in our baseline specification against the same-period income Ginis: there is a clear positive relationship, albeit with some dispersion.

It could therefore be argued that our interaction term (Gini interacted with an indicator of intergenerational mobility) is simply proxying for the interaction between the (time-varying) Gini coefficient and the (time-invariant) initial level of income inequality. We address this by controlling explicitly for the latter interaction.

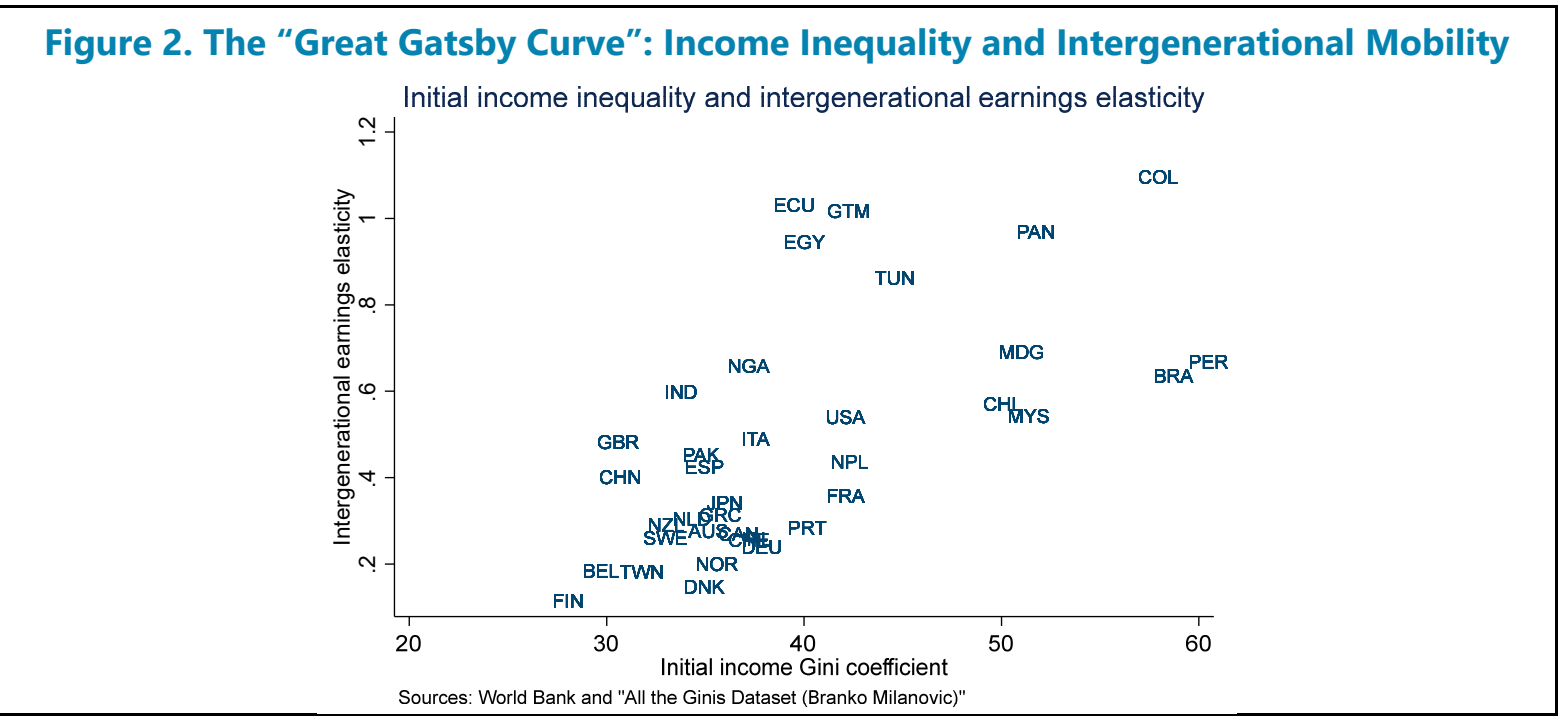

The results are shown in Table 3. Controlling for the interaction between the Gini coefficient and the initial level of the Gini does not fundamentally modify the baseline estimates. The negative effect of income inequality on growth conditional on the degree of intergenerational mobility remains statistically significant even after accounting for the "Great Gatsby curve." These results imply that there is something very specific about inequality of opportunity that is not reducible to a country's initial level of income inequality. Intuitively, even a high initial level of income inequality need not be a future constraint on growth provided that 
there are economic institutions which prevent these inequities from being transmitted across generations, that is, if the opportunity exists for the next generation to compete on a somewhat equal footing despite the income disparities of the parent's generation.

\section{Endogeneity of Income Inequality}

So far, we have attempted to assuage endogeneity concerns by using the five-year lagged values of the Gini coefficient - which are unlikely to be affected by current growth realizations - and by adopting the system-GMM estimation framework. In this sub-section we go further, by augmenting the system-GMM with external instruments for income inequality (see Aghion et al., 2009 for a similar robustness check within the system-GMM framework).

Our first external instrument for income inequality is the 10-year lagged level of the adolescent fertility rate, that is births per young females between 15 and 19 years old (data are from the World Bank's World Development Indicators). A high fertility rate among adolescents is likely to adversely affect their human capital accumulation and their prospects in the labor market when they become adult. This would worsen income distribution under the assumption that higher fertility rates are likely to be more prevalent for adolescents in low-income households (Kearney and Levine, 2012). Several other studies have also demonstrated the long-run negative effects of teen childbearing on mothers' outcomes (education, jobs, and wages) which would worsen income inequality further (Fletcher and Wolfe, 2009; and Hotz et al., 2005).

Indeed, in our data lagged adolescent fertility appears to be a very strong predictor of the income Gini (conditional on all our control variables including adolescent fertility interacted with measures of intergenerational mobility). Moreover, conditional on controlling for other determinants of growth such as lagged per capita income, investment, trade and the overall fertility rate, the 10-year lagged adolescent fertility rate seems less likely to affect growth directly. Thus, adolescent fertility presents a good case for being a strong instrument that satisfies the exclusion restriction.

We further instrument income inequality following the approach of a number of recent studies (Brueckner, 2013; and Brueckner and Lederman, 2015). The approach consists in constructing an income inequality variable that is adjusted for the impact that GDP per capita growth has on income inequality. This second instrument is "by construction" uncorrelated with the dependent variable, real per capita GDP growth. This instrument, too, is very strongly correlated with the Gini in a constructed first-stage regression where the Gini is regressed on this instrumental variable, and all the controls (including the instrument interacted with measures of intergenerational mobility). ${ }^{9}$ The Gini coefficient interacted with

\footnotetext{
${ }^{9}$ The auxiliary equation used to "extract" the residual component of income inequality which does not depend on growth is itself estimated using a panel IV approach in which growth is instrumented by its two- and threeyear lags. The residuals derived from this estimation are then used as instruments for income inequality in the growth regressions we are interested in.
} 
the measure of intergenerational elasticity is instrumented by the external instruments discussed above interacted with the measure of intergenerational elasticity.

These alternative approaches to controlling for the endogeneity of income inequality yield similar results to the baseline regressions, including for the threshold level of intergenerational elasticities above which income inequality has a detrimental effect on growth (Table 4).

\section{Policies To Level The Playing Field}

Although not the focus of this paper, it is worth noting a few policy implications of our results. In line with several recent papers, we find that reducing inequality can accelerate growth. To this we add that reducing income inequality is likely to yield higher dividends in economies characterized by high inequality of opportunity.

Over the long run, addressing the root causes of inequality of opportunity is crucial. Our paper shows that equalizing individual opportunity may promote not only equity but also ensure stable growth even in periods of large swings in income inequality. International evidence suggests that leveling the playing field requires structural reforms. More precisely, reforms that encourage human capital investment, reduce barriers to labor markets and promote equitable access to finance are likely to be critical.

Investing in human capital, especially at an early age is key to maximizing individual potential. Previous studies have emphasized the importance of lowering constraints to human capital accumulation. For example, Corak (2016) recognizes the need to invest in high quality early childhood, primary and secondary schooling as this is likely to be of relatively greater benefit to families lower in the socio-economic scale than investment devoted to subsidizing tertiary education. Marrero and Rodríguez (2012) document a positive association between lower school dropout rates and higher equality of opportunity. Countries can help to level the playing field by keeping students of all income backgrounds in the education system for a longer period of time.

Labor market inequality should also be addressed. The study by Marrero and Rodríguez (2012) highlights a positive association between long-term unemployment and inequality of opportunity in Europe. Hysteresis effects — such as skills depreciation — related to protracted unemployment exacerbate the risk of social exclusion and social immobility. Hence labor market rigidities that keep structural unemployment high should be eliminated to ensure better equality of opportunity.

Finally, widening access to finance would prevent the squandering of profitable investment opportunities. A recent study by Aghion et al. (2015) finds a positive and significant relationship between innovativeness and social mobility in the United States. The authors argue that the two are connected by the nature of creative destruction, which arises when there is scope for having new innovators (entrants) replace current firm owners (incumbents). Clearly there is a dead weight loss if credit constraints prevent low-income people with good ideas from implementing socially useful innovations. 


\section{Conclusion}

Although income inequality is widely recognized as undesirable, its relationship to economic growth has been difficult to establish. We have provided evidence that the relationship is mediated by equality of opportunity. Income inequality has a negative impact on growth in those economies characterized by low equality of opportunity, as measured by intergenerational mobility. The corollary is that not accounting for inequality of opportunity will tend to bias empirical estimates of the relationship between income inequality and growth. This is likely to be an important factor behind the inconclusive state of this literature.

We have not taken any stance on the precise channels through which the distribution of opportunities affects the income inequality-growth nexus. But we have suggested three. Unequal access to education, unequal access to labor markets and unequal access to finance, separately or in various combinations, could amplify the negative impact that a worsening of the income distribution has on growth. Measuring the importance of these and other channels would seem fertile ground for subsequent research, providing guidance on which policies to level the playing field are likely to yield the best returns. 


\section{APpendix}

\begin{tabular}{|lccccc|}
\hline Table A. Descriptive Statistics & \multicolumn{7}{c|}{} \\
\hline Variable & Obs. & Mean & S. Dev. & Min & Max \\
\hline GDP per capita growth rate & 890 & 2.2 & 3.8 & -30.7 & 24.6 \\
Income inequality (Gini) & 798 & 39.0 & 10.2 & 18.7 & 74.3 \\
Intergenerational earnings elasticity (GDIM) & 505 & 0.5 & 0.3 & 0.1 & 1.1 \\
Intergenerational education elasticity (GDIM) & 785 & 0.4 & 0.1 & 0.1 & 0.8 \\
Intergenerational earnings elasticity (Corak, 2016) & 226 & 0.4 & 0.2 & 0.2 & 1.2 \\
Intergenerational education elasticity (Hertz et al., 2007) & 310 & 0.6 & 0.2 & 0.3 & 1.0 \\
GDP per capita (log) & 893 & 9.0 & 1.1 & 6.0 & 11.3 \\
Investment-to-GDP ratio & 815 & 22.1 & 6.5 & 4.0 & 65.7 \\
Trade openness index & 846 & 74.5 & 51.1 & 6.5 & 410.2 \\
Years of schooling, secondary & 625 & 2.4 & 1.4 & 0.0 & 5.8 \\
Adolescent fertility rate & 913 & 0.1 & 0.1 & 0.0 & 0.2 \\
Growth-adjusted Gini coefficient & 323 & 0.6 & 6.0 & -9.2 & 21.8 \\
\hline
\end{tabular}




\begin{tabular}{|c|c|c|c|c|c|}
\hline \multicolumn{6}{|c|}{$\begin{array}{l}\text { Table 1. Effect of Income Inequality on Per Capita Growth: } \\
\text { System-GMM Estimates. Non-Overlapping Five-Year Periods }\end{array}$} \\
\hline $\begin{array}{l}\text { Dependent variable: } \\
\text { Real GDP per capita growth (in percent) }\end{array}$ & (1) & (2) & (3) & (4) & $(5)$ \\
\hline Gini & $\begin{array}{l}-0.00303 \\
(-0.0258)\end{array}$ & $\begin{array}{l}0.0647 \\
(0.514)\end{array}$ & $\begin{array}{l}0.0669 \\
(1.294)\end{array}$ & $\begin{array}{l}0.267^{*} \\
(1.701)\end{array}$ & $\begin{array}{l}-0.0982 \\
(-0.777)\end{array}$ \\
\hline Gini $\times$ Intergenerational elasticity (earnings): GDIM (2018) & & $\begin{array}{l}-0.211^{* \star} \\
(-1.998)\end{array}$ & & & \\
\hline Gini $\times$ Intergenerational elasticity (earnings): Corak (2016) & & & $\begin{array}{l}-0.169 * * \\
(-2.324)\end{array}$ & & \\
\hline Gini × Intergenerational elasticity (education): GDIM (2018) & & & & $\begin{array}{l}-0.848^{\star *} \\
(-2.094)\end{array}$ & \\
\hline Gini $\times$ Intergenerational elasticity (education): Hertz et al. (2007) & & & & & $\begin{array}{c}-0.392^{* *} \\
(-2.018)\end{array}$ \\
\hline Lagged real per capita GDP, log & $\begin{array}{l}-2.364^{*} \\
(-1.914)\end{array}$ & $\begin{array}{l}-5.748^{\star \star} \\
(-2.348)\end{array}$ & $\begin{array}{l}-5.724^{*} \\
(-2.327)\end{array}$ & $\begin{array}{l}-5.012^{\star \star} \\
(-2.560)\end{array}$ & $\begin{array}{l}-1.839 * \\
(-1.872)\end{array}$ \\
\hline Investment-to-GDP & $\begin{array}{l}0.107^{\star} \\
(1.944)\end{array}$ & $\begin{array}{l}0.0194 \\
(0.191)\end{array}$ & $\begin{array}{c}0.108 \\
(1.146)\end{array}$ & $\begin{array}{c}0.168 \\
(1.508)\end{array}$ & $\begin{array}{l}-0.110 \\
(-0.965)\end{array}$ \\
\hline Trade openness & $\begin{array}{c}0.0184^{* *} \\
(2.180)\end{array}$ & $\begin{array}{l}0.0218 \\
(1.532)\end{array}$ & $\begin{array}{l}0.0103 \\
(1.326)\end{array}$ & $\begin{array}{c}0.0485^{* *} \\
(2.088)\end{array}$ & $\begin{array}{l}-0.0274^{*} \\
(-1.753)\end{array}$ \\
\hline Education (secondary school, log) & $\begin{array}{l}3.128^{* *} \\
(2.150)\end{array}$ & $\begin{array}{l}5.964^{\star} \\
(1.678)\end{array}$ & $\begin{array}{c}4.207 \\
(1.118)\end{array}$ & $\begin{array}{c}4.894 \\
(1.527)\end{array}$ & $\begin{array}{l}-2.180 \\
(-0.605)\end{array}$ \\
\hline Intercept & $\begin{array}{c}16.03 \\
(1.235)\end{array}$ & $\begin{array}{l}45.91^{\star *} \\
(2.129)\end{array}$ & $\begin{array}{l}48.43^{* *} \\
(2.055)\end{array}$ & $\begin{array}{l}37.72^{\star *} \\
(2.035)\end{array}$ & $\begin{array}{c}41.26^{\star * \star} \\
(2.870)\end{array}$ \\
\hline Threshold level of intergenerational elasticity & & 0.30 & 0.39 & 0.32 & .. \\
\hline Percentage of countries above the intergenerational threshold & & $75 \%$ & $60 \%$ & $70 \%$ & .. \\
\hline AR[2]: p-value & 0.728 & 0.444 & 0.709 & 0.737 & 0.760 \\
\hline Sargan/Hansen OID: p-value & 0.023 & 0.217 & 0.707 & 0.386 & 0.736 \\
\hline No of instruments & 31 & 33 & 23 & 36 & 28 \\
\hline Observations & 428 & 270 & 149 & 412 & 201 \\
\hline Number of countries & 101 & 55 & 22 & 89 & 36 \\
\hline $\begin{array}{l}\text { z-statistics in par } \\
\star * \star * \\
p<0.01,{ }^{* *} p<0 .\end{array}$ & $\begin{array}{l}\text { ntheses } \\
5,{ }^{*} p<0.1\end{array}$ & & & & \\
\hline
\end{tabular}




\begin{tabular}{|c|c|c|}
\hline $\begin{array}{l}\text { Dependent variable: } \\
\text { Real GDP per capita growth (in percent) } \\
\end{array}$ & (1) & (2) \\
\hline Gini & $\begin{array}{l}-0.345 \\
(-0.825)\end{array}$ & $\begin{array}{c}0.227 \\
(0.765)\end{array}$ \\
\hline Gini × Intergenerational elasticity (earnings): GDIM (2018) & $\begin{array}{l}-0.184^{\star *} \\
(-2.356)\end{array}$ & \\
\hline Gini × Intergenerational elasticity (education): GDIM (2018) & & $\begin{array}{l}-0.370^{* *} \\
(-1.998)\end{array}$ \\
\hline Gini squared & $\begin{array}{c}0.00488 \\
(0.909)\end{array}$ & $\begin{array}{c}-0.000618 \\
(-0.175)\end{array}$ \\
\hline Lagged real per capita GDP, log & $\begin{array}{c}-7.274^{\star \star \star} \\
(-3.621)\end{array}$ & $\begin{array}{c}-3.494^{* * *} \\
(-3.171)\end{array}$ \\
\hline Lagged investment-to-GDP & $\begin{array}{l}0.0814 \\
(1.213)\end{array}$ & $\begin{array}{c}0.157^{* * *} \\
(2.956)\end{array}$ \\
\hline Trade openness & $\begin{array}{c}0.00775 \\
(0.265)\end{array}$ & $\begin{array}{l}0.0300^{*} \\
(1.884)\end{array}$ \\
\hline Education (secondary school, log) & $\begin{array}{c}12.15^{* * *} \\
(3.646)\end{array}$ & $\begin{array}{l}3.486^{* *} \\
(2.053)\end{array}$ \\
\hline Intercept & $\begin{array}{c}62.07^{* * *} \\
(3.026)\end{array}$ & $\begin{array}{l}22.32^{* *} \\
(1.967)\end{array}$ \\
\hline$A R[2]: p$-value & 0.879 & 0.919 \\
\hline Sargan/Hansen OID: $p$-value & 0.550 & 0.118 \\
\hline No of instruments & 32 & 34 \\
\hline Observations & 294 & 412 \\
\hline Number of countries & 56 & 89 \\
\hline
\end{tabular}




\begin{tabular}{|c|c|c|c|}
\hline $\begin{array}{l}\text { Dependent variable: } \\
\text { Real GDP per capita growth (in percent) }\end{array}$ & $(1)$ & (2) & (3) \\
\hline Gini & $\begin{array}{l}0.00705 \\
(0.0634)\end{array}$ & $\begin{array}{l}0.0739 \\
(0.833)\end{array}$ & $\begin{array}{l}0.335^{\star *} \\
(2.387)\end{array}$ \\
\hline Gini × Intergenerational elasticity (earnings): GDIM (2018) & & $\begin{array}{l}-0.247^{\star \star} \\
(-2.497)\end{array}$ & \\
\hline Gini × Intergenerational elasticity (education): GDIM (2018) & & & $\begin{array}{l}-0.640 * * \\
(-1.972)\end{array}$ \\
\hline Gini $\times$ Initial Gini & $\begin{array}{c}-0.00252 \\
(-1.467)\end{array}$ & $\begin{array}{c}0.00290 \\
(1.146)\end{array}$ & $\begin{array}{c}0.000443 \\
(0.263)\end{array}$ \\
\hline Lagged real per capita GDP, log & $\begin{array}{l}1.379 \\
(0.640)\end{array}$ & $\begin{array}{l}-1.145 \\
(-0.657)\end{array}$ & $\begin{array}{l}-1.940 \\
(-1.108)\end{array}$ \\
\hline Lagged investment-to-GDP & $\begin{array}{c}0.144 \\
(1.347)\end{array}$ & $\begin{array}{l}0.147^{\star *} \\
(2.022)\end{array}$ & $\begin{array}{c}0.110 \\
(1.364)\end{array}$ \\
\hline Trade openness & $\begin{array}{l}-0.00679 \\
(-0.444)\end{array}$ & $\begin{array}{l}-0.00728 \\
(-0.583)\end{array}$ & $\begin{array}{l}0.0241^{*} \\
(1.675)\end{array}$ \\
\hline Education (secondary school, log) & $\begin{array}{c}-5.201 \\
(-1.197)\end{array}$ & $\begin{array}{c}-1.232 \\
(-0.295)\end{array}$ & $\begin{array}{c}1.689 \\
(0.847)\end{array}$ \\
\hline Intercept & $\begin{array}{c}-3.176 \\
(-0.173)\end{array}$ & $\begin{array}{c}9.941 \\
(0.713)\end{array}$ & $\begin{array}{c}10.54 \\
(0.655)\end{array}$ \\
\hline AR[2]: $p$-value & 0.202 & 0.890 & 0.168 \\
\hline Sargan/Hansen OID: p-value & 0.484 & 0.05 & 0.348 \\
\hline No of instruments & 24 & 26 & 22 \\
\hline Observations & 322 & 212 & 245 \\
\hline Number of countries & 57 & 33 & 48 \\
\hline \multicolumn{4}{|c|}{$\begin{array}{l}\text { z-statistics in parentheses } \\
{ }^{* * *} p<0.01,{ }^{* *} p<0.05,{ }^{*} p<0.1\end{array}$} \\
\hline
\end{tabular}




\begin{tabular}{|c|c|c|c|c|}
\hline \multicolumn{5}{|c|}{$\begin{array}{c}\text { Table 4. Effect of Income Inequality on Per Capita Growth: } \\
\text { System-GMM IV Estimates. Non-Overlapping Five-Year Periods }\end{array}$} \\
\hline $\begin{array}{l}\text { Dependent variable: } \\
\text { Real GDP per capita growth (in percent) }\end{array}$ & (1) & (2) & (3) & (4) \\
\hline Gini & $\begin{array}{l}0.0373 \\
(0.400)\end{array}$ & $\begin{array}{l}0.0359 \\
(1.155)\end{array}$ & $\begin{array}{c}0.149 \\
(1.139)\end{array}$ & $\begin{array}{l}0.0415 \\
(0.476)\end{array}$ \\
\hline Gini × Intergenerational elasticity (earnings): GDIM (2018) & $\begin{array}{l}-0.113^{* *} \\
(-2.013)\end{array}$ & & & \\
\hline Gini $\times$ Intergenerational elasticity (earnings): Corak (2016) & & $\begin{array}{l}-0.0721^{*} \\
(-1.758)\end{array}$ & & \\
\hline Gini $\times$ Intergenerational elasticity (education): GDIM (2018) & & & $\begin{array}{l}-0.458^{\star *} \\
(-2.179)\end{array}$ & \\
\hline Gini $\times$ Intergenerational elasticity (education): Hertz et al. (2007) & & & & $\begin{array}{l}-0.149^{\star} \\
(-1.677)\end{array}$ \\
\hline Lagged real per capita GDP, log & $\begin{array}{l}-2.921^{* \star *} \\
(-2.682)\end{array}$ & $\begin{array}{l}-4.554^{*} \\
(-1.835)\end{array}$ & $\begin{array}{l}-2.229 * \\
(-1.779)\end{array}$ & $\begin{array}{l}-0.434 \\
(-0.444)\end{array}$ \\
\hline Investment-to-GDP & $\begin{array}{c}0.259 * * * \\
(3.787)\end{array}$ & $\begin{array}{l}0.0973 \\
(1.109)\end{array}$ & $\begin{array}{c}0.124^{* * *} \\
(2.951)\end{array}$ & $\begin{array}{l}0.0327 \\
(0.295)\end{array}$ \\
\hline Trade openness & $\begin{array}{c}0.00943 \\
(0.744)\end{array}$ & $\begin{array}{l}0.0112^{*} \\
(1.800)\end{array}$ & $\begin{array}{l}-0.00226 \\
(-0.300)\end{array}$ & $\begin{array}{l}-0.0165 \\
(-1.104)\end{array}$ \\
\hline Education (secondary school, log) & $\begin{array}{c}2.066 \\
(0.660)\end{array}$ & $\begin{array}{c}8.535 \\
(1.573)\end{array}$ & $\begin{array}{c}0.895 \\
(0.348)\end{array}$ & $\begin{array}{l}-1.956 \\
(-0.874)\end{array}$ \\
\hline Intercept & $\begin{array}{l}21.47^{* *} \\
(2.252)\end{array}$ & $\begin{array}{l}32.35^{\star} \\
(1.694)\end{array}$ & $\begin{array}{l}20.28^{*} \\
(1.712)\end{array}$ & $\begin{array}{c}12.07 \\
(1.562)\end{array}$ \\
\hline Threshold level of intergenerational elasticity & 0.331 & 0.498 & 0.325 & 0.278 \\
\hline Percentage of countries above the intergenerational threshold & $75 \%$ & $50 \%$ & $70 \%$ & $100 \%$ \\
\hline AR[2]: $p$-value & 0.342 & 0.490 & 0.701 & 0.318 \\
\hline Sargan/Hansen OID: p-value & 0.050 & 0.792 & 0.086 & 0.104 \\
\hline No of instruments & 25 & 13 & 14 & 27 \\
\hline Observations & 294 & 131 & 355 & 201 \\
\hline Number of countries & 56 & 22 & 86 & 36 \\
\hline $\begin{array}{l}\text { z-statistics in pa } \\
* * * p<0.01,{ }^{* *} p<0\end{array}$ & $\begin{array}{l}\text { theses } \\
* p<0.1\end{array}$ & & & \\
\hline
\end{tabular}




\section{REFERENCES}

Aiyar, S., Duval, R., Puy, D., Wu, Y., and Zhang, L., 2018, "Growth Slowdowns and the Middle Income Trap," Japan and the World Economy, Vol. 48, pp. 22-37.

Aiyar, S. and Feyrer, J., 2002, "A Contribution to the Empirics of Total Factor Productivity," Dartmouth College Working Paper No. 02-09 (Hanover, New Hampshire: Dartmouth College).

Aghion, P., Akcigit, U., Bergeaud, A., Blundell, R., and Hemous, D., 2015, "Innovation and Top Income Inequality," CEPR Discussion Paper No. 10659 (London: Centre for Economic and Policy Research).

Aghion, P., Bacchetta, P., Rancière, R., and Rogoff, K., 2009, "Exchange Rate Volatility and Productivity Growth: The Role of Financial Development," Journal of Monetary Economics, 56(4), pp. 494-513.

Alesina, A. and Rodrik, D., 1994, "Distributive Politics and Economic Growth," Quarterly Journal of Economics, Vol. 109(2), pp. 465-490.

Alesina, A., Stantcheva, S., and Teso, E., 2017, "Intergenerational Mobility and Preferences for Redistribution," NBER Working Paper No. 23027 (Cambridge, Massachusetts: MIT Press).

Andrews, D., and Leigh, A., 2009, "More Inequality, Less Social Mobility," Applied Economics Letters, 16, Issue 15, pp. 1489-1492.

Banerjee, A. and Duflo, E., 2003, "Inequality and Growth: What Can the Data Say?" Journal of Economic Growth - Springer, Vol. 8(3) (September), pp. 267-299.

Barro, R., 1991, "Economic Growth in a Cross Section of Countries," Quarterly Journal of Economics, Vol. 106(2), pp. 407-43.

Benhabib, J., and Spiegel, M., 1994, "The Role of Human Capital in Economic Development: Evidence from Agrregate Cross-Country Data," Journal of Monetary Economics, 1994, Vol. 34(2), pp. 143-74.

Berg, A., Ostry, J., and Zettlemeyer, J., 2012, "What Makes Growth Sustained?” Journal of Development Economics, Vol. 98(2), pp. 149-166.

Blundell, R., and Bond, S., 1998, "Initial Conditions and Moment Restrictions in Dynamic Panel Data Models," Journal of Econometrics 87, pp. 115-143.

Bradbury, K., and Triest, R., 2016, "Inequality of Opportunity and Aggregate Economic Performance," Russell Sage Foundation Journal of the Social Sciences 2, pp. 178-201. 
Brueckner, M., 2013, "On the Simultaneity Problem in the Aid and Growth Debate," Journal of Applied Econometrics, John Wiley \& Sons, Ltd., Vol. 28(1), pp. 126-150.

Brueckner, M. and Lederman, D., 2015, "Effects of Income Inequality on Aggregate Output,” Policy Research Working Paper Series 7317 (Washington: World Bank).

Brueckner, M., Dabla Norris, E., and Gradstein, M., 2015, "National Income and its Distribution," Journal of Economic Growth - Springer, Vol. 20(2) (June), pp. 149-175.

Brzezinski, M., 2015, "Inequality of Opportunity in Europe Before and After the Great Recession," Working Papers 353, ECINEQ, Society for the Study of Economic Inequality.

Checchi, D., Vito Peragine, V., and Serlenga, L., 2016, "Inequality of Opportunity in Europe: Is There a Role for Institutions?" in Inequality: Causes and Consequences, ed. by Lorenzo Cappellari, Solomon W. Polachek, and Konstantinos Tatsiramos, Research in Labor Economics, Vol. 43, Emerald Group Publishing Limited, pp. 1-44.

Cingano, F., 2014, "Trends in Income Inequality and its Impact on Economic Growth," OECD Social, Employment and Migration Working Paper No. 163 (Paris: Organisation for Economic Co-operation and Development).

Corak, M., 2006, "Do Poor Children Become Poor Adults? Lessons for Public Policy from a Cross Country Comparison of Generational Earnings Mobility," Research on Economic Inequality, Volume 13, pp. 143-188.

Corak, M., 2016, "Inequality from Generation to Generation: The United States in Comparison,” IZA Discussion Paper No. 9929 (Bonn: Institute for the Study of Labor (IZA)).

Corak, M., 2013, “Income Inequality, Equality of Opportunity, and Intergenerational Mobility," Journal of Economic Perspectives, 27(3), pp. 79-102.

Fletcher, J. and Wolfe, B., 2009, "Education and Labor Market Consequences of Teenage Childbearing: Evidence Using the Timing of Pregnancy Outcomes and Community Fixed Effects," Journal of Human Resources, 44(2), pp. 303-325.

Forbes, K., 2000, “A Reassessment of the Relationship Between Inequality and Growth," American Economic Review, American Economic Association, Vol. 90(4) (September), pp. 869-887.

GDIM, 2018, Global Database on Intergenerational Mobility, Development Research Group, World Bank (Washington).

Galor, O. and Zeira, J., 1993, "Income Distribution and Macroeconomics," Review of Economic Studies, Vol. 60, pp. 35-52. 
Hertz, T., Jayasundera, T., Piraino, P., Selcuk, S., Smith, N., and Verashchagina, A., 2007, "The Inheritance of Educational Inequality: International Comparisons and Fifty-Year Trends," The B.E. Journal of Economic Analysis \& Policy, Vol. 7: Iss. 2 (Advances), Article 10.

Hotz, J., Williams McElroy, S., and Sanders, S., 2005, "Teenage Childbearing and its Life Cycle Consequences: Exploiting a Natural Experiment," Journal of Human Resources, Vol. 40(3), pp. 683-715.

Hsieh, C., Hurst, E., Jones, C., and Klenow, P., 2013, "The Allocation of Talent and U.S. Economic Growth,” NBER Working Paper 18693 (Cambridge, Massachusetts: National Bureau of Economic Research).

Inglehart, R., 2016, "Modernization, Existential Security and Cultural Change: Reshaping Human Motivations and Society," in Advances in Culture and Psychology, ed. M. Gelfand, C.Y. Chiu and Y-Y Hong (New York: Oxford University Press).

Inglehart, R., and Norris, P., 2011, Sacred and Secular, $2^{\text {nd }}$ ed. (New York: Cambridge University Press).

Inglehart, R., and Norris, P., 2016, "Trump, Brexit and the Rise of Populism: Economic Have-Nots and Cultural Backlash," Faculty Research Working Paper RW16-06 (Cambridge, Massachusetts: Harvard Kennedy School).

Kearney, M. and Levine, P., 2012, "Why Is the Teen Birth Rate in the United States So High and Why Does It Matter?” Journal of Economic Perspectives, 26(2), pp. 141-163.

Kraay, A., 2015, "Weak Instruments in Growth Regressions: Implications for Recent Crosscountry Evidence on Inequality and Growth,” Policy Research Working Paper Series 7494 (Washington: World Bank).

Marrero, G., and Rodríguez, J., 2012, "Inequality of Opportunity in Europe," Review of Income and Wealth 58, pp. 597-621.

Marrero, G. and Rodríguez, J., 2013, “Inequality of Opportunity and Growth,” Journal of Development Economics, 104, pp. 107-122.

Marrero, G., Rodríguez, J., and Van der Weide, R., 2016, "Unequal Opportunity, Unequal Growth,” Policy Research Working Paper Series 7853 (Washington: World Bank).

Milanovic, Branko, 2016, Global Inequality: A New Approach for the Age of Globalization (Cambridge, Massachusetts: Harvard University Press).

Narayan, A., Van der Weide, R., Cojocaru, A., Lakner, C., Redaelli, S., Mahler, D., Ramasubbaiah, R., and Thewissen, S., 2018, "Fair Progress? Economic Mobility Across Generations Around the World," Equity and Development (Washington: World Bank). 
OECD, 2016, Society at a Glance 2016: OECD Social Indicators (Paris: Organisation for Economic Co-operation and Development). http://dx.doi.org/10.1787/9789264261488-en

Ostry, J., and Berg, A., 2011, "Inequality and Unsustainable Growth; Two Sides of the Same Coin?” IMF Staff Discussion Note No. 11/08 (Washington: International Monetary Fund).

Ostry, J., Berg, A., and Tsangarides, C., 2014, "Redistribution, Inequality, and Growth," IMF Staff Discussion Note No. 14/02 (Washington: International Monetary Fund).

Ostry, J., Loungani, P., and Berg, A., 2018, Confronting Inequality: How Societies Are Free to Choose Inclusive Growth (New York: Columbia University Press).

Panizza, U., 2002, "Income Inequality and Economic Growth: Evidence from American Data," Journal of Economic Growth, Vol. 7(1), pp. 25-41.

Peterson, E. W. F., 2017, Is Economic Inequality Really a Problem? A Review of the Arguments, Social Sciences, MDPI, Vol. 6(4), pp. 1-25.

Persson, T., and Tabellini, G., 1994, "Is Inequality Harmful for Growth? Theory and Evidence," American Economic Review, 84, pp. 600-621.

Piketty, Thomas, 2014, Capital in the $21^{\text {st }}$ Century (Cambridge, Massachusetts: The Belknap Press of Harvard University Press).

Roodman, D., 2009, A Note on the Theme of Too Many Instruments, Oxford Bulletin of Economics and Statistics, Department of Economics, University of Oxford, Vol. 71(1), pp. $135-158$.

Smeeding, T. and Latner, J., 2015, PovcalNet, WDI and 'All the Ginis': A Critical Review, The Journal of Economic Inequality, 13(4) (December), pp. 603-628,.

Stiglitz, Joseph E., 2013, The Price of Inequality: How Today's Divided Society Endangers our Future. New York: W.W. Norton and Company. 